\title{
MRT 解決方略の男女差についての解析
}

\author{
*椎名久美子 \\ **鈴木賢次郎 \\ $* * *$ 青野由利
}

\section{1 はじめに}

図学教育に関連して、学生の空間認識力をメンタル・ローテーション・テスト [1] (MRT) を用いて評価する試みがなされている [2][3]。一般に空間認識力には男女差があると言わ れており、Wilson ら [4] が行った調査では、14６0 歳までの全世代にわたって MRT 得 点に男女差がみられた。椎名ら [5][6] は視線追跡法を用いて、高・低得点者の MRT の問 題解決過程を比較した。その結果、高得点者のほとんどが単純で規則的な心的回転方略 で問題を解くのに対して、低得点者の解決方略は、圥長な心的回転以外に、図形の特徵 抽出、図形構造の符号化などの多様な方略を用いて解くことを示した。すなわち、高・ 低得点者間に解決方略の違いがあることを示した。しかし、これらの研究における被験 者は、高得点者には男子が多く、低得点者には女子が多かったため、上述の解决方略の 違いが、得点の違いによるものか、あるいは、男女差によるものかは、必ずしも明らか ではなかった。本研究では、これまでに蓄積した調査デー夕を元に、統計的な手法を用 いて誤答傾向の比較を行い、同一得点群の男女における方略の違いを考察した。

\section{MRT の問題構成}

MRT は Vandenberg ら [1] が開発したペーパーテストである。MRT の課題は、与えら れた基準立体と同一の立体を 4 つの選択肢の中から 2 つ選ぶものである。課題は Part1、 Part2 各 10 問ずつで計 20 問あり、大学生の場合は各パートを制限時間 3 分で解く。1 問 につき 2 点が与えられ、満点は 40 点となる。

MRT の各問題は、一見すると互いに似ているが、Vandenberg ら [1] は、誤選択肢の 図形的性質が異なる 2 種類の問題で MRT を構成した。1つは、誤選択肢と基準立体が 鏡像関係にある問題であり、以後、鏡像問題と呼ぶことにする。もう1つは、誤選択肢 と基準立体が鏡像関係にない問題であり、以後、異物問題と呼ぶことにする。ペーパー テストでは、鏡像問題と異物問題とが 2 問おきに並んでいる。

\section{3 分析結果及び考察}

本研究では、'90〜'94にかけて椎名 [7] が行った調査に'95 年の東大での調査結果を加 えたデータを用いた。被験者は、男子 1490 名、女子 535 名、合計 2025 名である。

*大学入試センター研究開発部

* * 東京大学教養学部情報 - 図形科学教室/東京大学大学院総合文化研究科

$* * *$ 東京大学大学院総合文化研究科修士課程 


\section{1 同一得点群の作成}

図 1(a)(b) に、男女別の MRT 得点ヒストグラムを、それぞれの平均值と共に示す。な お、全被験者の MRT 得点の平均值は 24.7、標準偏差は 8.8 である。男子の得点は女子 より高い得点域に分布しており、高得点者には男子が多く女子が少なく、低得点者には 男子が少なく女子が多い。同一得点群で男女の誤答傾向を比較するために、以下のよう に被験者群を選定した。

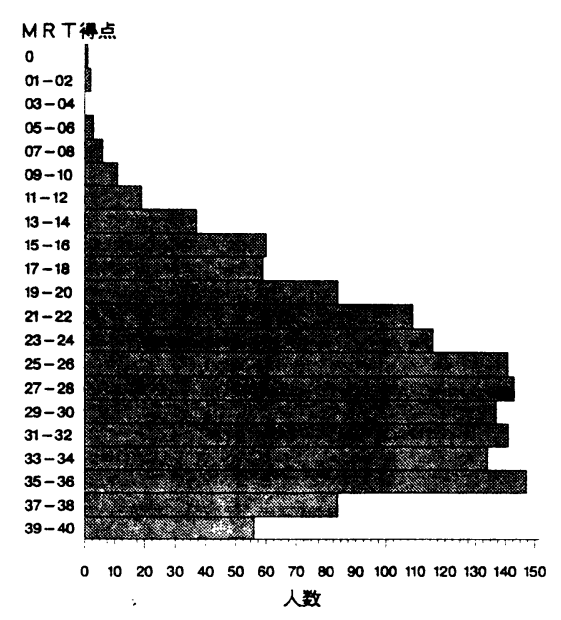

(a) 男子

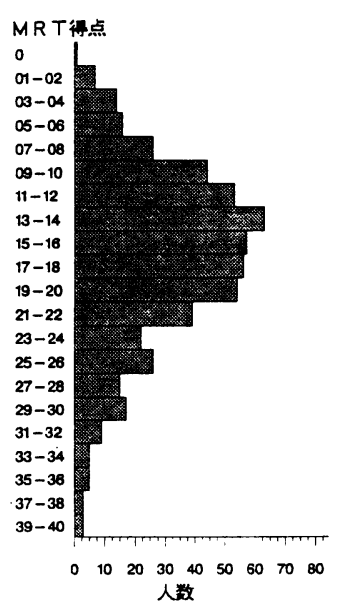

(b) 女子

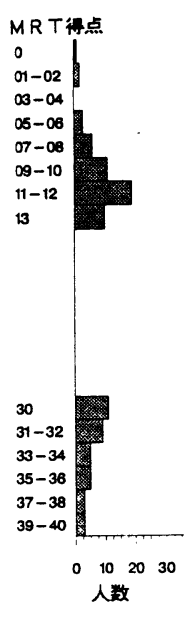

(c) 高·低得点群

図 1: MRT 得点ヒストグラム

平均值士標準偏差を目安に、被験者数を考慮して、高得点域を 30〜 40 点、低得点域を 0〜13 点とした。少ないほうの人数にそろえて、各得点での男女の人数が等しくなるよ うにした。このようにして、1. 高得点男子群 (30～40 点、36 人)、2. 高得点女子群 $(30$ ～ 40 点、36 人)、3. 低得点男子群 ( $0 \sim 13$ 点、 52 人)、 4 . 低得点女子群 ( $0 \sim 13$ 点、 52 人)、 の 4 群を作成した。図 1 (c) に高・低得点群における MRT 得点の人数分布を示す。群 1 と 2 での MRT 平均值は 33.1、群 3 と 4 での MRT 平均值は 10.3 である。

\section{2 同一得点群での男女比較}

\subsection{1 高得点群}

各問題で、選択肢を 2 つ選んだ被験者はその問題を解答し終ったとみなすことが出来 る。このような被験者の割合を完答率と呼ぶことにする。制限時間のもとでの完答率は、 問題を解く速さの目安と考えられる。また、各問題で完答した被験者のみについて算出 した平均得点を、以後完答者平均得点と呼ぶ。完答者平均得点は、完答した被験者がど れだけ正確に各問題を解けたかを示しており、問題の難易度の目安と考えられる。

図 2 に高得点群の完答率と完答者平均得点を男女別に示す。完答率、完答者平均得点 の傾向は、男女でほほ一致している。完答率を $\chi^{2}$ 検定した結果、男女で有意差が認めら れる問題はなかった。完答者平均得点を $t$ 検定した結果、男女で有意差が認められる問 
題はなかった。男女とも、問題 3、15、19 で完答者平均得点が他の問題に比べて低い傾 向が見られるが、これは、前報 [8] で報告したように、被験者が心的回転で問題を解いて いることを示している。すなわち、高得点群に関しては、問題解決の速度と解決方略は 男女で似た傾向を示すと言える。
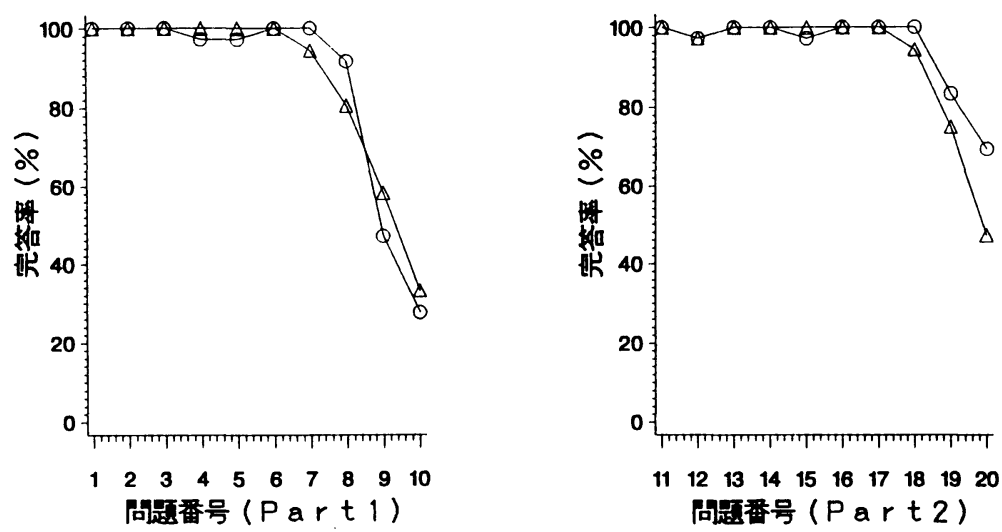

(a) 完答率
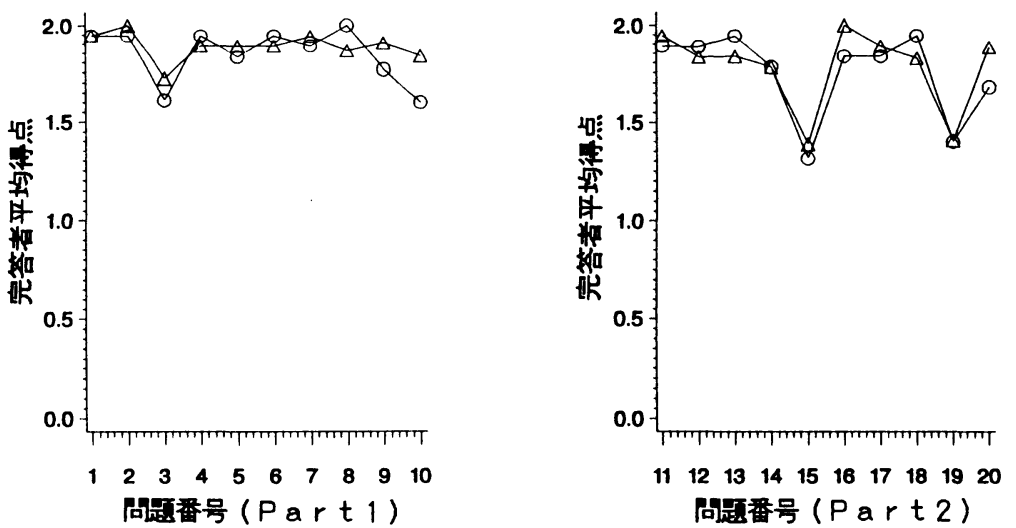

(b) 完答者平均得点

図 2: 高得点群の完答率と完答者平均得点 $(\bigcirc$ : 男子, $\triangle$ : 女子)

\subsection{2 低得点群}

図 3に低得点群の完答率と完答者平均得点を男女別に示す。完答率に関して、完答者 数を $\chi^{2}$ 検定あるいは Fisher の直接確率を用いて検定した結果を表 1 に示す (有意な差が 認められた問題のみ)。Part1 の問 8、9、10 と Part2 の問 13、18、20 において男女で有 意差が認められた。

Part1 では、パートの後ろのほうの 3 問で男子のほうが女子より完答率が高いことか ら、問題を解く速さが男子のほうが速いと考えられる。Lohman[9] は、MRT の基であ る Shepard-Metzler 課題 [10]について、提示時間を制御することにより、速度と正確さ の関係を男女間で比較した。その結果、同じ正答率を達成するのに要する時間は、女子 
のほうが男子より長い傾向が示された。本分析でも低得点群の男女間での解く速さの違 いが示されたのは、Lohman[9] の分析結果と一致する傾向と言える。Part2では、パー トの前のほうの問 13 で女子のほうが完答率が高く、パートの後ろのほうの問 18 と問 20 で男子のほうが完答率が高い。これは、低得点群の男子において、問題の配置順に解か ずに、わからない問題をとばして次の問題に進む傾向を示唆しており、時間制限が厳し いテストに取り組む方針の男女差と言えるかもしれない。
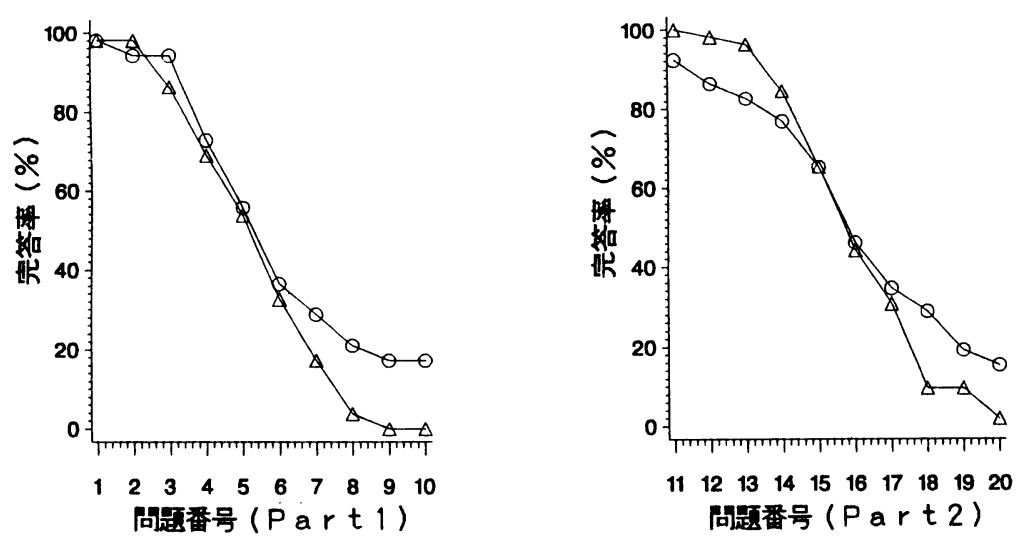

(a) 完答率
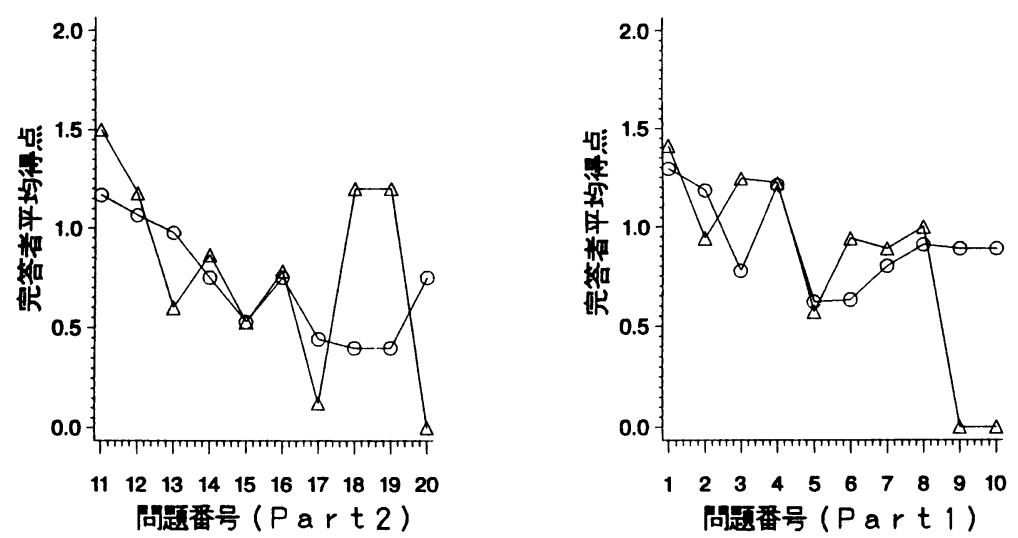

(b) 完答者平均得点

図 3: 低得点群の完答率と完答者平均得点 ( $\bigcirc$ : 男子, $\triangle$ : 女子)

完答者平均得点を $t$ 検定した結果、低得点群では男女間では、問題 3 において完答者 平均得点に有意な差が認められた $(t=2.312, p<0.05)$ 。すなわち、低得点群において は、男子は女子より問題 3 を間違えやすいと言える。問題 3 は Part1 の前のほうに配置 されている問題なので男女共に完答率が高い。すなわち、問題 3 は、女子より男子にとっ て、やっても出来ない難しい問題と考えられる。なお、問題 3 以外では完答者平均得点 に男女間の有意差は認められなかったが、この原因として、低得点群では、各 Part の後 ろのほうの問題になると、完答者数が非常に少なくなって有意差の検出力が弱くなるこ とが挙げられる。椎名ら [8] は、被験者が心的回転で解いたと仮定すると、問題 3 での 
表 1: 低得点群における完答者数 (男女各 52 名中)

\begin{tabular}{|c|c|c|c||c|c|c|c|}
\hline 問題 & 男子 (人) & 女子 (人) & $p$ 値 & 問題 & 男子 $($ 人) & 女子 $($ 人) & $p$ 值 \\
\hline \hline 8 & 11 & 2 & 0.008 & 13 & 43 & 50 & 0.026 \\
9 & 9 & 0 & $2.68 \times 10^{3 *}$ & 18 & 15 & 5 & 0.013 \\
10 & 9 & 0 & $2.68 \times 10^{3 *}$ & 20 & 8 & 1 & $0.031^{*}$ \\
\hline
\end{tabular}

*は Fisher の直接確率

誤りを説明できるとしている。本分析で、低得点男子にとっての問題 3 の完答者平均得 点が女子より低いことから、低得点群においては、男子は女子より心的回転で解く傾向 が強いと考えられる。

\section{3 鏡像問題と異物問題}

表 2 に各得点群における鏡像問題と異物問題の得点の平均値を示す。鏡像問題と異物問 題の得点差を $t$ 検定したところ、低得点女子群で有意であった $(t=-2.390, p=0.021<$ 0.05)。これは、低得点女子群にとっては、異物問題より鏡像問題で間違えやすいことを 示している。

表 2: 鏡像問題と異物問題の平均値 $(()$ 内は標準偏差 $)$ と差の検定

\begin{tabular}{|c|c||c|c|c|c|}
\hline 得点群 & 被験者数 & 鏡像問題 & 異物問題 & $t$ 値 & $p$ 値 \\
\hline \hline 高得点男子群 & 36 & $16.58(2.18)$ & $16.56(2.31)$ & 0.052 & 0.959 \\
高得点女子群 & 36 & $16.83(2.17)$ & $16.31(2.25)$ & 1.012 & 0.319 \\
低得点男子群 & 52 & $5.12(2.00)$ & $5.19(2.26)$ & -0.181 & 0.857 \\
低得点女子群 & 52 & $4.52(2.38)$ & $5.79(2.47)$ & -2.390 & 0.021. \\
\hline
\end{tabular}

図形の特徴抽出による方略では、特徵として、上下の腕の平行・垂直がしばしば用い られることが指摘されている [5][6]。鏡像問題では誤選択肢が基準図形と鏡像関係にある ので、腕の平行垂直だけに着目すると間違える可能性がある。すなわち、鏡像問題は心 的回転以外の方略で解くと間違えやすい問題と言える。表 2 に示したように、低得点女 子では、鏡像問題を間違えやすい傾向が有意であるが、低得点男子には有意差は認めら れない。以上から、低得点群では、女子のほうが、心的回転以外の方略で問題を解く傾 向が強いと考えられる。

Lohman[9] は、Shepard-Metzler 課題の 2 つの図形の角度差が大きな場合に、等しい 正答率を得るのに必要な課題提示時間の男女差が有意であったことから、女子が用いる 方略として、回転以外の試みをしているか、double-checking かを用いていると推測して いる。本分析は、低得点群の女子が心的回転以外の方略を用いて解く傾向を示しており、 Lohman[9] の推測とある程度一致している。 


\section{MRT 得点と男女差}

本研究では、男女で人数分布を一致させた同一得点群を作成して、同一得点群での男 女差を比較した。本分析で作成した高得点群では、問題を解く速度と解決方略に男女差 は認められなかった。一方、低得点群では、1. 男子は女子より解く速度が速い傾向、2. 女子は男子より心的回転以外の方略を用いる傾向、が見られた。すなわち、低得点群に おいては、MRT の解決速度、解決方略に男女差が認められた。

本研究を進めるにあたり、検定手法等に関して御助言をいただいた大学入試センター 研究開発部柳井晴夫教授に対し、ここに感謝の意を表します。

\section{参考文献}

[1] Vandenberg, S. G., and Kuse, A. R.:"Mental rotations, a group test of threedimensional spatial visualization", Perceptual and Motor Skills 47(1978), p.599-604.

[2] Miller, C. L., Wiley, E. W., and Bertoline, G. R.: "Strategies for improving the visualization ability of engineering graphics students", Proceedings of the 4th. ICECGDG (Miami, 1990).

[3] McCuistion, P. J.: "Static vs. dynamic visuals in computer assisted instruction", Engineering Design Graphics Journal (Spring, 1991), p.25-33.

[4] Wilson, J. R., DeFries, J. C., McClearn, G. E., Vandenberg, S. G., Johnson, R. C., and Rashad, M. N. : "Cognitive abilities: use of family data as a control to assess sex and age differences in two ethnic groups", International Journal of Aging and Human Development 6(1975), p.261-276.

[5] 椎名久美子、牧野国嗣、斎藤孝明、鈴木賢次郎、神宮敬: “アイカメラによる MRT 問題解決過程の解析”, 1992 年度図学会大会 (中部) 学術講演論文集, p.136-143.

[6] 椎名久美子、斎藤孝明、鈴木賢次郎: “アイカメラによる MRT 問題解決過程の解析 (2) -Shepard-Metzler 課題の解決過程-”, 1995 年度図学会大会（関西）学術講演論 文集, p.131-136.

[7] 椎名久美子: "Spatial ability evaluated by a Mental Rotations Test and Its Relations to Undergraduate Graphics Eduation", 平成 6 年度東京大学大学院総合文化研究科 博士論文, p.25.

[8] 椎名久美子、鈴木賢次郎: “図学教育における前後 MRT の結果”, 1991 年度図学会 大会 (東京) 学術講演論文集, p.83-88.

[9] Lohman, D. F.: "The effect of speed-accuracy tradeoff on sex differences in mental rotation", Perception and Psychophysics 39(1986), 427-436.

[10] Shepard, R. N., and Metzler, J.: "Mentál rotation of three-dimensional objects", Science 171(1971), 701-703. 